\title{
Modeling of Infilled Frames With Openings
}

\author{
Panagiotis G. Asteris ${ }^{1}$, Ioannis P. Giannopoulos ${ }^{*}, 2$ and Christis Z. Chrysostomou ${ }^{3}$ \\ ${ }^{I}$ Computational Mechanics Laboratory, School of Pedagogical and Technological Education, 14124 Heraklion, Athens, \\ Greece; ${ }^{2}$ Laboratory of Structural Engineering, Department of Architectural Engineering, National Technical Univer- \\ sity of Athens, 106 82, Athens, Greece; ${ }^{3}$ Department of Civil Engineering \& Geomatics, Cyprus University of Technol- \\ ogy, 3603 Limassol, Cyprus
}

\begin{abstract}
This work concerns an assessment of the behavior of infilled frames. The feasibility of possible immediate implementation of some recent developments both in analysis and design of infilled frames for practical design is investigated. It is now widely recognized that masonry infill panels used in reinforced concrete $(\mathrm{R} / \mathrm{C})$ frame structures, significantly enhance both the stiffness and the strength of the surrounding frame. However, their contribution is often not taken into account because of the lack of knowledge of the composite behaviour of the surrounding frame and the infill panel.

Currently, Seismic Design Codes (EC8 - Part 1, ASCE 41-06) contain provisions for the calculation of stiffness of solid infilled frames mainly by modeling infill as a 'diagonal strut.' However, such provisions are not provided for infilled frames with openings. The present study, proposes analytical equations of the reduction factor, which is expressed as the ratio of the effective width of the diagonal strut of an infill with openings over that of the a solid infill, in order to be able to calculate the initial lateral stiffness of reinforced concrete (RC) frames with infills that have openings. The validity of the proposed equations is demonstrated by comparing our results against work done by various researchers.
\end{abstract}

Keywords: Finite element method, infilled frames, masonry, seismic response, stiffness.

\section{INTRODUCTION}

It has been known for long that masonry infill walls affect the strength and stiffness of infilled frame structures. In seismic areas, ignoring the frame-infill panel interaction is not always on the safe side, since, under lateral loads, the infill walls dramatically increase the stiffness by acting as a compressed diagonal 'strut/area', resulting, thus, in a possible change of the seismic demand due to significant reduction in the natural period of the composite structural system $[1,2]$.

The rationale behind neglecting infill walls in the design process is partly attributed to incomplete knowledge of the behaviour of quasi-brittle materials such as unreinforced masonry (URM), of the composite behaviour of the frame and the infill, as well as due to the lack of conclusive experimental and analytical results to substantiate a reliable design procedure for this type of structures, despite the extensive experimental efforts [3-9] and analytical investigations [10-20] over the past decades. Moreover, due to the large number of interacting parameters, if the infill wall is to be considered in the analysis and design stages, a modelling problem arises because of the many possible failure modes that need to be evaluated with a high degree of uncertainty. Therefore, it is not surprising that no consensus has emerged leading to a unified approach for the design of infilled-frame systems in spite of more than six decades of research. However, it is generally accepted that under lateral loads an infill

*Address correspondence to this author at the Laboratory of Structural Engineering, Department of Architectural Engineering, National Technical University of Athens, 106 82, Athens, Greece.E-mail: igianno@cantab.net wall acts as a diagonal strut connecting the two loaded corners, an approach that is only applicable to the case of infill walls without openings on the diagonal of the infill panel. The reader is referred to Moghaddam and Dowling [21] and Asteris et al. [22] for an extensive review of research on testing and modeling of masonry infilled frames up to 2010.

In this paper the macro-modeling of infilled frames is briefly presented along with a reduction parameter for the representation of infills with openings. Then some analytical studies are presented which are calibrated against experimental results, to show the effect of the openings on the period of vibration of structures and on interstorey drifts using nonlinear dynamic analysis.

\section{MACRO-MODELLING OF MASONRY INFILL}

Since the first attempts to model the response of the composite infilled-frame structures, experimental and conceptual observations have indicated that a diagonal strut with appropriate geometrical and mechanical characteristics could possibly provide a solution to the problem (Fig. 1).

Early research on the in-plane behavior of infilled frame structures undertaken at the Building Research Station, Watford (later renamed Building Research Establishment, and now simply BRE) in the 1950s served as an early insight into this behavior and confirmed its highly indeterminate nature in terms solely of the normal parameters of design [23-25]. On the basis of these few tests a purely empirical interaction formula was later tentatively suggested by Wood [26] for use in the design of tall framed buildings. By expressing the composite strength of an infilled frame directly in terms of the separate strengths of the frame and infill, he short- 
circuited a mass of confusing detail and he recognized the desirability of a higher load factor where strengths were most dependent on the infills.

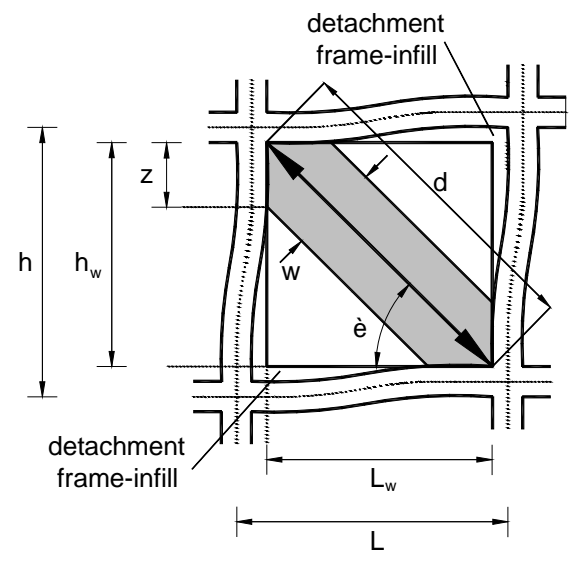

Fig. (1). Masonry infill frame sub-assemblage.

\subsection{Single-Strut Models}

In the early sixties, Polyakov [27] suggested the possibility of considering the effect of the infilling in each panel as equivalent to diagonal bracing, and this suggestion was later adopted by Holmes [28], who replaced the infill by an equivalent pin-jointed diagonal strut made of the same material and having the same thickness as the infill panel and a width defined by

$$
\frac{w}{d}=\frac{1}{3}
$$

where $d$ is the diagonal length of the masonry panel. The "one-third" rule was suggested as being applicable irrespective of the relative stiffness of the frame and the infill. One year later, Stafford Smith [29], based on experimental data from a large series of tests using masonry infilled steel frames, found that the ratio $w / d$ varied from 0.10 to 0.25 . On the second half of the sixties, Stafford Smith and his associates using additional experimental data $[3,4,30]$ related the width of the equivalent diagonal strut to the infill/frame contact lengths using an analytical equation, which has been adapted from the equation of the length of contact of a free beam on an elastic foundation subjected to a concentrated load [31]. They proposed the evaluation of the equivalent width $\lambda_{h}$ as a function of the relative panel-to-framestiffness parameter, in terms of

$\lambda_{h}=h \sqrt[4]{\frac{E_{w} t_{w} \sin 2 \theta}{4 E h_{w}}}$

where $E_{w}$ is the modulus of elasticity of the masonry panel, $E I$ is the flexural rigidity of the columns, $t_{w}$ the thickness of the infill panel and equivalent strut, $h$ the column height between centerlines of beams, $h_{w}$ the height of infill panel, and $\theta$ the angle whose tangent is the infill height-to-length aspect ratio, being equal to

$\theta=\tan ^{-1}\left(\frac{h_{w}}{L_{w}}\right)$ in which $L_{w}$ is the length of infill panel (all the above parameters are explained in Fig. (1).

Based on experimental and analytical data, Mainstone [32] proposed an empirical equation for the calculation of the equivalent strut width, given by

$\frac{w}{d}=0.16 \lambda_{h}^{-0.3}$

Mainstone and Weeks [33] and Mainstone [34], also based on experimental and analytical data, proposed an empirical equation for the calculation of the equivalent strut width:

$\frac{w}{d}=0.175 \lambda_{h}^{-0.4}$

This formula was included in FEMA-274 (Federal Emergency Management Agency 1997) [35] for the analysis and rehabilitation of buildings as well as in FEMA-306 (Federal Emergency Management Agency 1998) [36], as it has been proven to be the most popular over the years. This equation was accepted from the majority of researchers dealing with the analysis of infilled frames.

\subsection{Multiple-Strut Models}

Crisafulli [37] investigated the influence of different multi-strut models on the structural response of reinforced concrete infilled frames, focusing on the stiffness of the structure and the actions induced in the surrounding frame. Numerical results, obtained from the single-two and threestrut models, were compared with those corresponding to a refined finite element. The lateral stiffness of the structure was similar in all the cases considered, with smaller values for two- and three-strut models. It must be noted that, for the multi-strut models, the stiffness may significantly change depending on the separation between struts. The single-strut model underestimates the bending moment because the lateral forces are primarily resisted by a truss mechanism. On the other hand, the two-strut model leads to larger values than those corresponding to the finite element model. A better approximation is obtained from the three-strut model, although some differences arise at the ends of both columns. Although the single-strut and the triple-strut models constitutes sufficient tools for the prediction of the overall response, Crisafulli adopted the double-strut model approach, accurate enough and less complicated compared to the other models.

More recently, Crisafulli and Carr [38] proposed a new macro-model in order to represent, in a rational but simple way, the effect of masonry infill panels. The model is implemented as a four-node panel element which is connected to the frame at the beam-column joints. Internally, the panel element accounts separately for the compressive and shear behavior of the masonry panel using two parallel struts and a shear spring in each direction as shown in Fig. (2).

This configuration allows an adequate consideration of the lateral stiffness of the panel and of the strength of masonry panel, particularly when a shear failure along mortar joints or diagonal tension failure is expected. Furthermore, the model is easy to apply in the analysis of large infilled frame structures. The main limitation of the model stems 
from its simplicity, since the panel is connected to the beamcolumn joints of the frame, being thus not able to properly predict the bending moment and shear forces in the surrounding frame.

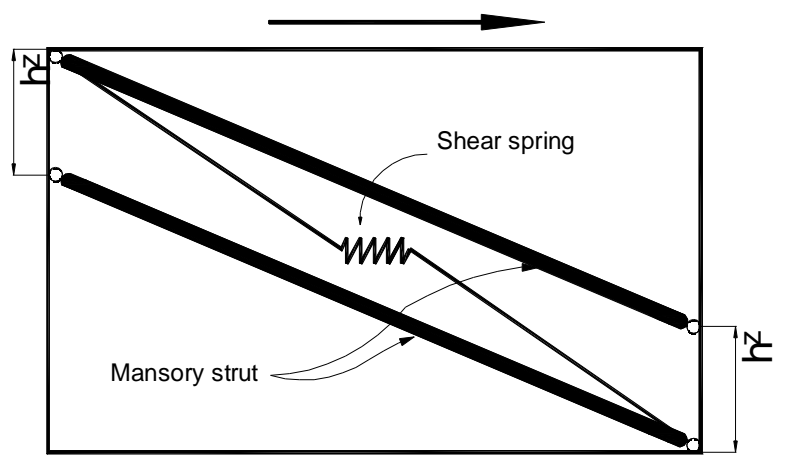

Fig. (2). Multi-strut model proposed by Crisafulli and Carr [38] for masonry infill panel (only the struts and the shear spring active in one direction are represented.

The proposed model for masonry infill panels was implemented in RUAUMOKO [39], a computer-based analytical tool able to accurately model three-dimensional structures whilst providing ancillary design data such as earthquake spectra. The proposed model has been also implemented in the program SeismoStruct [40] by various researchers, demonstrating the accuracy of the model to evaluate the nonlinear response of the structure. SeismoStruct is an internet-downloadable fiber-based finite element package capable of predicting the large displacement behavior of space frames under static or dynamic loading, considering both geometric nonlinearities and material inelasticity and fully accounting for the spread of inelasticity along the member length and across the section depth.

\subsection{Effect of Openings in the Lateral Stiffness of Infill Walls}

Although infill walls usually have oversized openings, research has mainly focused on the simple case of infill wall without openings. Research on infill walls with openings is mostly analytical, restricted to special cases, and as such cannot provide rigorous comparison to actual cases because of its focus on specific materials used and specific types of openings. It is worth noting that the contribution of the infill wall to the frame lateral stiffness is reduced significantly when the structure is subjected to reversed cyclic loading, as in real structures under earthquake conditions.

In order to investigate the effect of openings in the lateral stiffness of masonry infill walls, a finite element technique proposed by Asteris $[15,18]$ has been used in this paper. The basic characteristic of this analysis is that the infill/frame contact lengths and the contact stresses are estimated as an integral part of the solution, and are not assumed in an adhoc way.

In brief, according to this technique, the infill finite element models are considered to be linked to the surrounding frame finite element models at two corner points (only), at the ends of the compressed diagonal of the infill (points $A$ and B in Fig. 3a). Then, the nodal displacements are computed and checked whether the infill model points overlap the surrounding frame finite elements. If the answer is positive, the neighboring points (to the previous linked) are also linked and the procedure is repeated. If the answer is negative, the procedure is stopped and the derived deformed mesh is the determined one (Fig. 3b).

Using this technique, analytical results are presented on the influence of the opening size on the seismic response of masonry infilled frames. Fig. (4) shows the variation of the $\lambda$ factor as a function of the opening percentage (opening area/infill wall area), for the case of an opening on the compressed diagonal of the infill wall (with aspect ratio of the opening the same as that of the infill). As expected, the increase in the opening percentage leads to a decrease in the frame's stiffness. Specifically, for an opening percentage greater than $50 \%$ the stiffness reduction factor tends to zero.

The findings of the present parametric study using the finite-element method, lead to the following relationship for the infill wall stiffness reduction factor $\lambda$

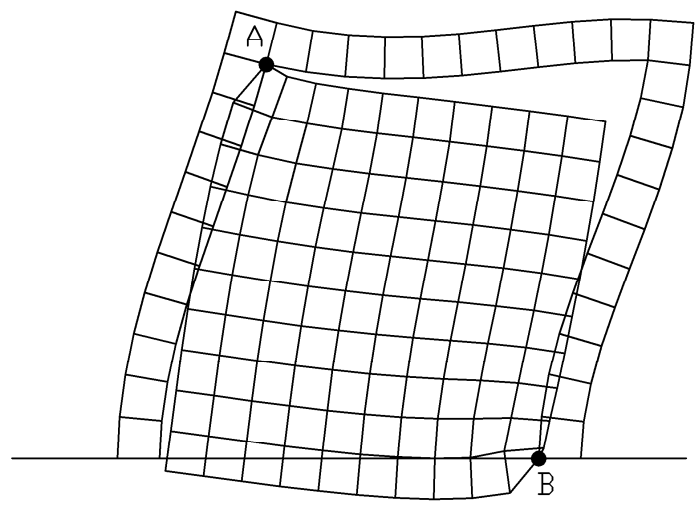

(a) 1 st derived mesh

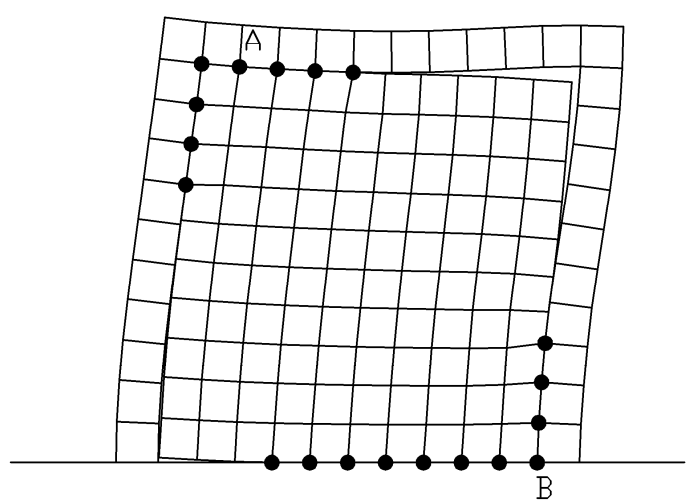

(b) 8th-final derived mesh

Fig. (3). Deformed meshes of an one-storey one-bay infilled frame using the finite element technique proposed by Asteris [15, 18] (Method of Contact Points). 


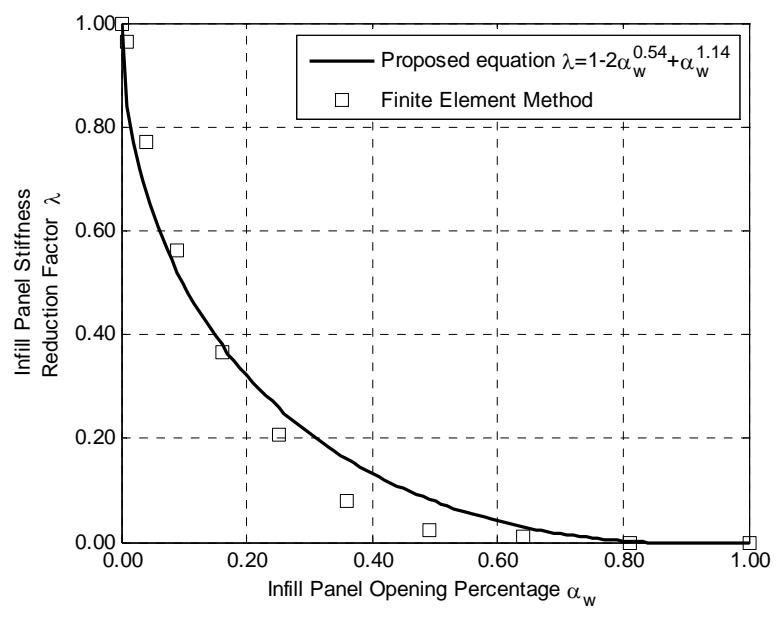

Fig. (4). Infill panel stiffness reduction factor in relation to the opening percentage.

$\lambda=1-2 \alpha_{\mathrm{w}}^{0.54}+\alpha_{\mathrm{w}}^{1.14}$

in which $\alpha_{w}$ is the infill wall opening percentage (area of opening to the area of infill wall).

The above coefficient is not yet calibrated with other experimental data. However, it can now be used to find the equivalent width of a strut for the case of an infill with opening by multiplying the results of Eqns 1, 4 and 5 above. It can also be used to modify the equations of the Crisafulli model, which is described below.

\section{NUMERICAL EXAMPLE}

In order to illustrate the inadequacy of the single-strut models to represent the structural response of infill walls with openings in frame structures, a case-study was carried out, employing a reinforced concrete frame, whereby the infill walls are modeled with each of the two approaches. For the multi-strut case, the Crisafulli double-strut model has been chosen, since it is satisfactorily precise to represent accurately the local effect between the infill and the frame and less complicated than a triple-strut model. The singlestrut model used is a rather 'gross' model that can be employed in commercial packages. It consists of a pair of diagonal elastic struts that are active at all times, each of which has a stiffness of $50 \%$ of the calculated infill-wall stiffness.

The relative accuracy of the models is assessed through comparison with experimental results obtained from pseudodynamic tests of a full-scale four-storey and three-bay reinforced concrete frame, which was tested at the ELSA reaction-wall laboratory within the framework of the ICONS research programme [41]. The frame was infilled with brick walls that included openings of different aspect ratios dimensions (Fig. 5). It can be regarded as representative of the design and construction practice of the 1960's in Southern Europe, designed to withstand only vertical loads, without satisfying the modern seismic-code design requirements.

The experimental seismic response was obtained with pseudo-dynamic testing, i.e. a step by step integration technique to compute the displacement response of the frame that was subjected to three different numerically specified

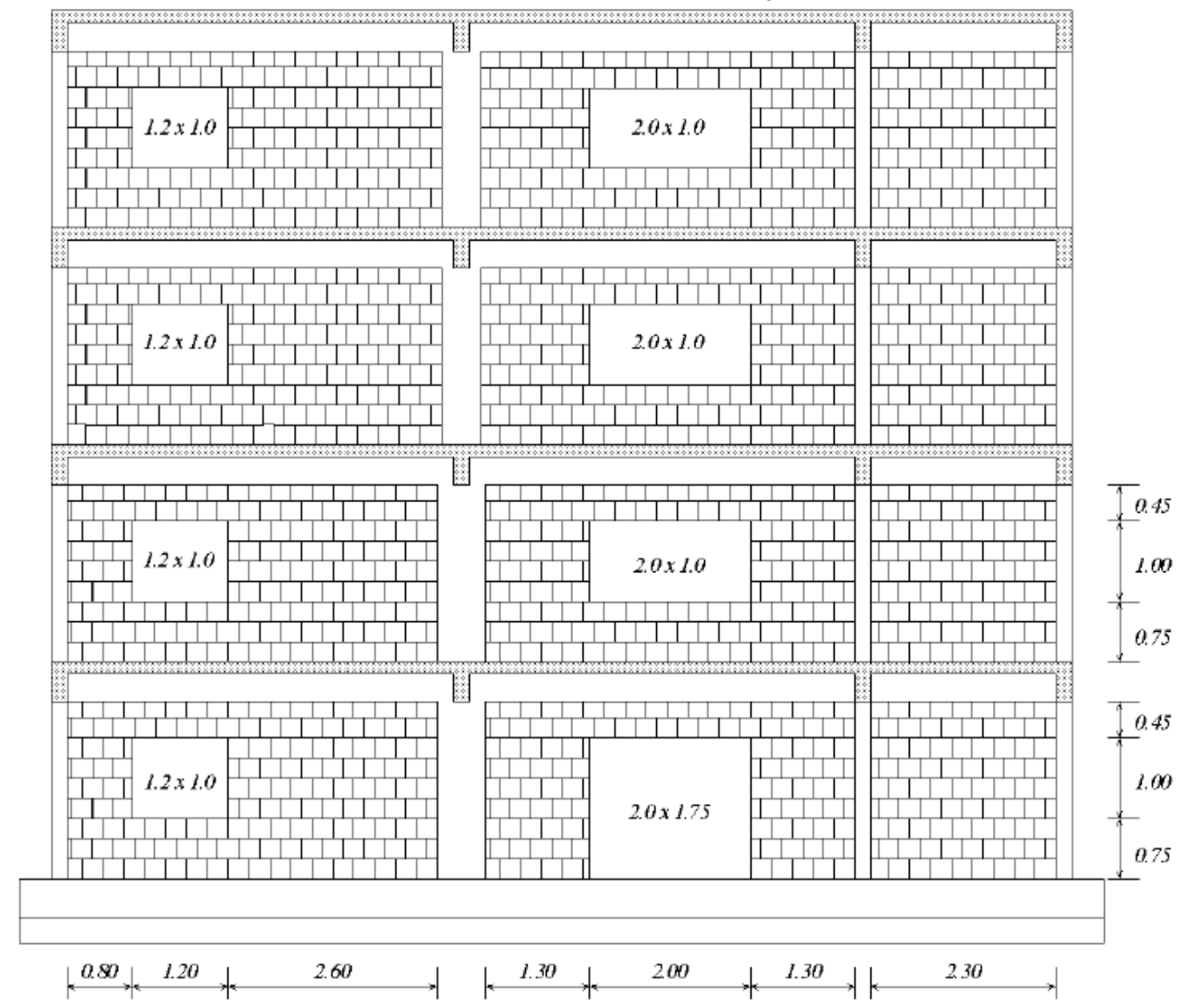

Fig. (5). Elevation view of the infilled frame-Location and dimensions of openings [40]. 

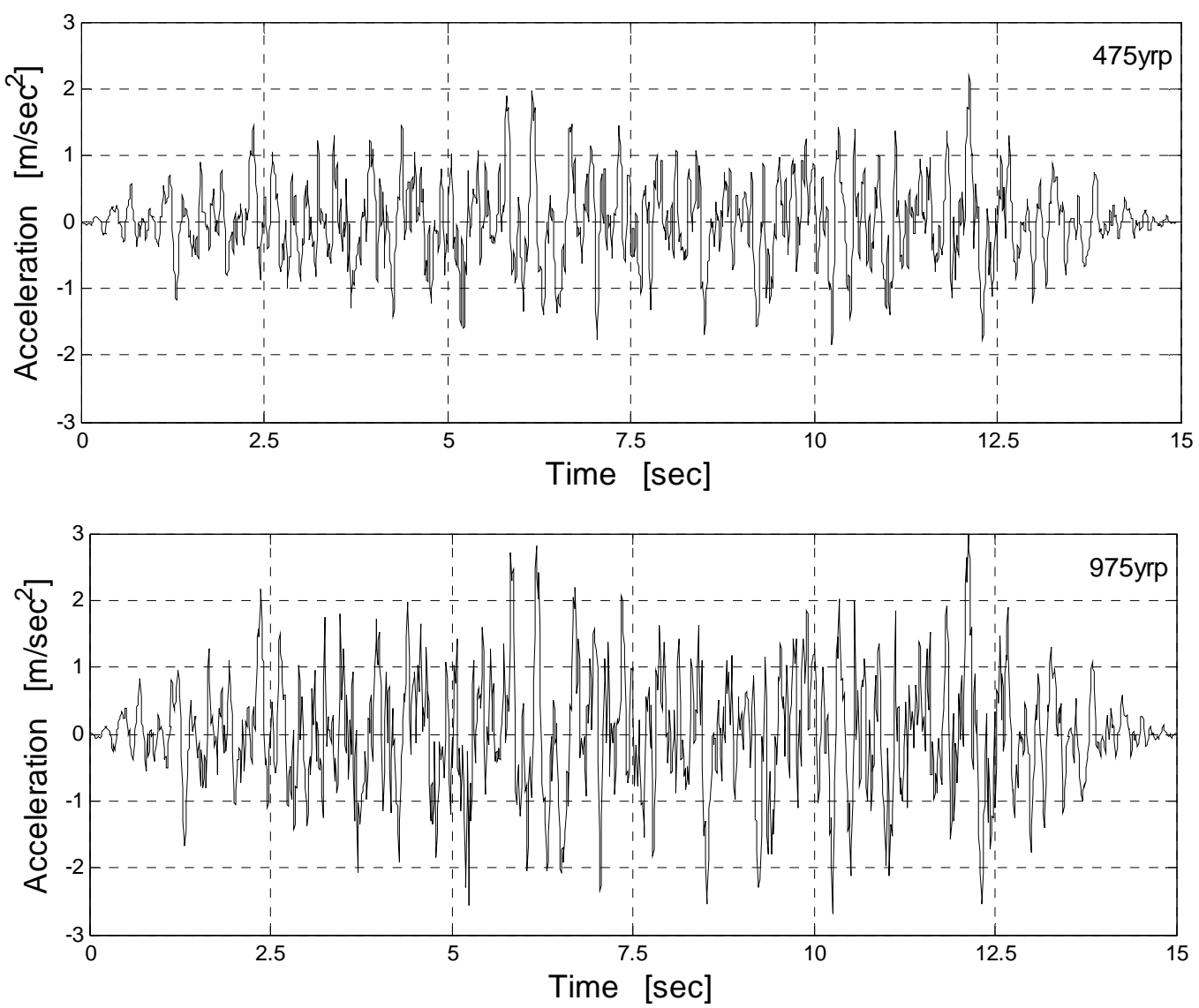

Fig. (6). Ground motion acceleration for $475 \& 975 y r p$.

seismic records, utilizing the nonlinear restoring forces actually developed during the test. The input seismic motions were chosen to be representative of a moderate-high European hazard scenario. The acceleration time-histories were artificially generated [42] and three of increasing return periods of 475, 975 and 2000 years were used for the experiment (only the first two were employed in the present study and are shown in Fig. 6).

The nonlinear structural analysis program SeismoStruct [40] was employed for the analyses. In section 3.1, a comparison is made between the analysis results for the above structure using a single strut and a multi-strut model. This is done to calibrate the model based on experimental data. Then, the same frame is used but having infills with the same percentage of openings in all the panels at all floors. The analyses are used to examine the influence of openings on the period of the structure and the inter-story drift. The effectiveness of the proposed model to represent the effects of soft-stories ('pilotis') is also examined.

\subsection{Verification of the Numerical Model}

- Before proceeding with the analyses of the infilled frame, there was a need to verify the accuracy of the numerical model of the bare frame. The aim was to ensure that the numerical model represents satisfactorily the bare frame before inserting the various infilled openings. By limiting the other parameters of uncertainty, the infilled panel model is rendered in fact the only variable, the effect of which should be examined.
- An eigenvalue-modal analysis was undertaken to provide a first insight into the structure. The values of the periods of the $1^{\text {st }}$ up to the $4^{\text {th }}$ mode are computed and presented in Table $\mathbf{1}$, together with the experimental estimates of the natural frequencies. In order to provide data for modal identification of the bare frame, a very low intensity excitation was applied to the structure before the pseudodynamic test took place, similar as an non-destructive test. More details about these methods, which are based on time-domain linear models, can be found elsewhere [43].

Table 1. Periods and Mass Contributions of Bare Frame Model

\begin{tabular}{|c|c|c|c|}
\hline Period [sec] & Experimental & Analytical & $\begin{array}{c}\text { Mass contribution } \\
{[\%]}\end{array}$ \\
\hline \hline $1^{\text {st }}$ & 0.64 & 0.63 & 83.02 \\
\hline $2^{\text {nd }}$ & 0.22 & 0.21 & 10.78 \\
\hline $3^{\text {rd }}$ & 0.13 & 0.13 & 3.58 \\
\hline $4^{\text {th }}$ & 0.09 & 0.09 & 2.60 \\
\hline
\end{tabular}

From Table 1, it can be observed that the fundamental period is dominant (mass contribution $83.02 \%$ ). The value of the fundamental period for a typical 4-storey building is high, reflecting the flexibility of the structure mainly due to the absence of infill panels. By comparing the $1^{\text {st }}$ period of 

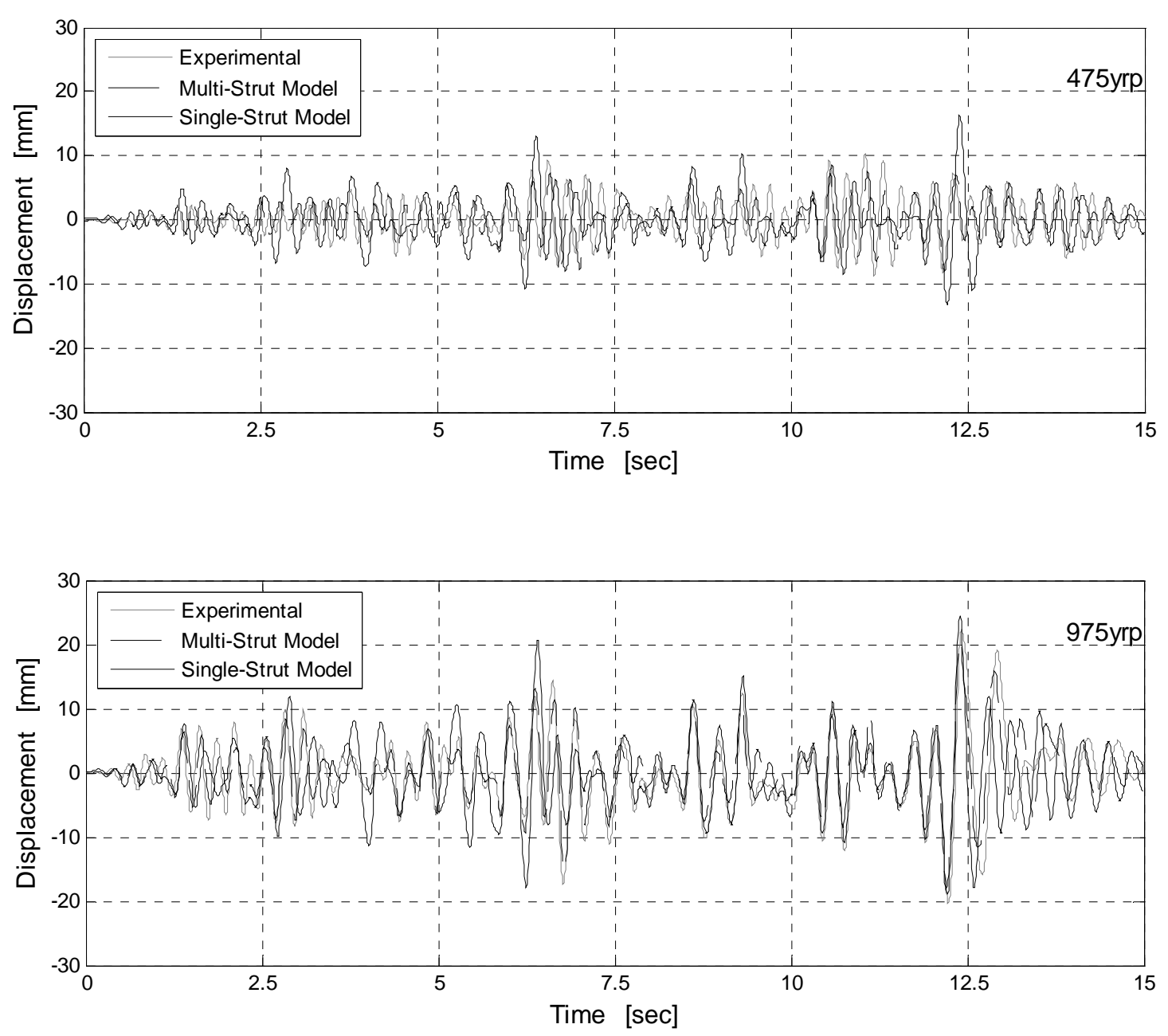

Fig. (7). Comparison of the top displacement of the infill frame for the two structural models (475 \& 975yrp record).

the test frame $(0.64 \mathrm{secs})$ with the fundamental period of the numerical model $(0.63 \mathrm{secs})$, it is noted that there is a remarkable agreement between them. The same conclusion can be reached for the rest of the periods, showing the accuracy of the analytical model used.

\subsection{Single-Strut Model vs. Multiple-Strut Model}

Representative numerical results obtained from the single and multi-strut models are depicted in Fig. (7) for acceleration time-histories of increasing return periods of 475 and 975 years. It can be easily concluded that the multi-strut model provides a very good fit to the experimental results and therefore a better approximation with the use of finite elements is strongly justified. However, it should be stressed that the correct modeling of the infill required the selection of the value of a significant number of parameters, a difficult and intricate task, which is not always suitable in everyday practice.

On the contrary, the single-strut model lacks a similar ability to represent adequately the experimental behavior, providing significantly less accurate results. This is entirely attributed to the inability of such over-simplified models to reproduce all the complex aspects of the infill walls' behavior. Similar to the above conclusions have been drawn re- garding the displacement and the shear-force profiles along the height of the building.

\subsection{Comparison of the Experimental and Analytical Model of the Tested Infilled Frame}

- After the preliminary verification of the numerical model for the bare frame, the infilled panel elements were implemented in the model. A dynamic time-history analysis was carried out in the infilled frame with the aim to simulate the pseudo-dynamic tests conducted in the laboratory. The accuracy of the numerical model is evaluated by comparing the results of the analysis with the experimental results. The comparison was done in terms of time-history maximum inter-storey drift and base shear, as can be seen in Figs. (8) and (9). In Fig. (8), the maximum experimental and numerical drifts for each storey, are plotted together with the drift values corresponding to three damage limit states. More details regarding these limits are described elsewhere [44]. It can be observed that for return period of 475 years, the maximum drift values are varying close to the (IO) limit state, while for a return period of 975 years, the peak value at the $1^{\text {st }}$ storey exceed the $(\mathrm{CP})$ limit state.

- In Fig. (9), a comparison in terms of time-histories, instead of comparison of the instantaneous peak values of 
base shear is presented; it is considered to be more representative because an overall picture of the precision of the numerical model is obtained.

- A first overall observation is that the analytical results demonstrate a good match with those of the experiment. Some differences are identified in several parts of the time-histories. For example, at the beginning of the timehistory, corresponding to the $475 y$ rs record of the model, few differences occurring at the peaks of a limited number of cycles are observed, while at the middle and at the end of the same records the model tends to underestimate the base shear. This under-estimation is due to the nonlinear behavior that is exhibited by the infill and the structure at that stage. No further suggestions to overcome this problem is presented at this stage.
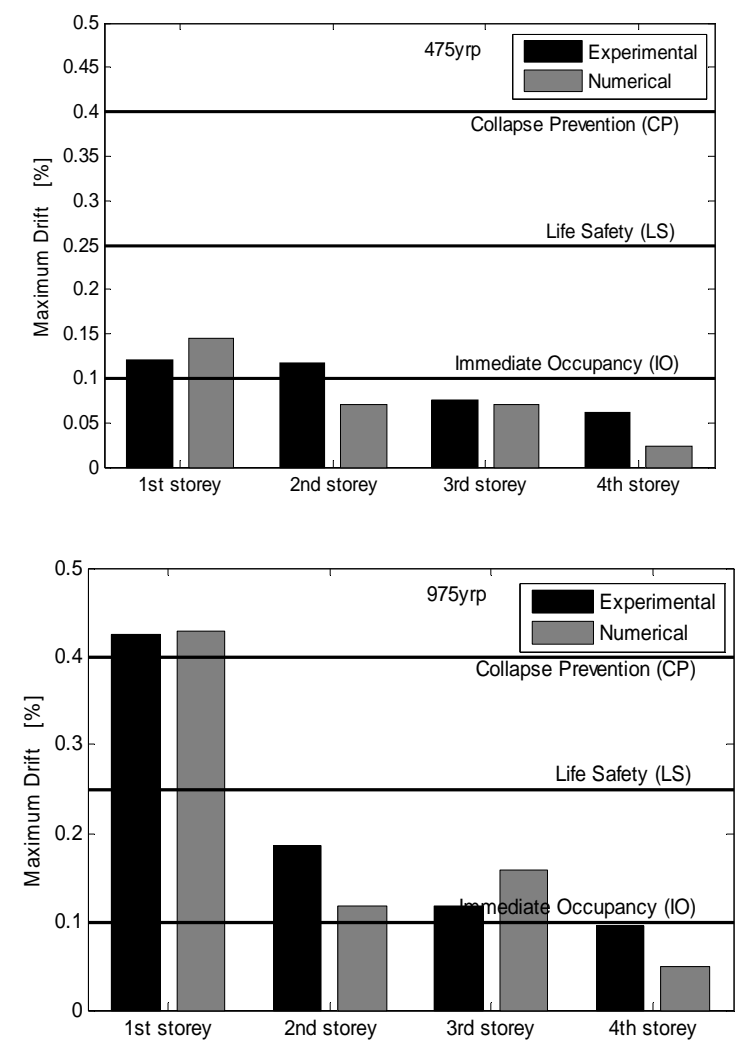

Fig. (8). Maximum inter-storey drift for the $475 \& 975$ yrp tests: comparison with drift values corresponding to the three limit states.

\subsection{Effect of Openings on Fundamental Periods}

The infill wall enhances the lateral stiffness of the framed structures; however, the presence of openings within the infill wall will reduce the lateral stiffness. Fig. (10) shows the variation of the fundamental period with the opening percentage. All values are also presented in a tabular form (Table 2), where the mass contribution for the fundamental period is given as well. The fundamental period increases as the opening size increases, as expected, due to reduction in stiffness of the model. Such variation of periods cannot be considered using the formulas proposed by design codes. There is no clear relationship between the opening size and the fundamental period, but it is certain that the opening size influence on the fundamental period of the structure.

By comparing the fundamental periods of a fully infilled (FI) and a bare frame (BF), a difference of magnitude of about 9 is observed, which is in agreement with the literature [2]. An elastic spectrum according to the standard EC 8 [45] for ground type A was chosen, as can be seen in Fig. (11). In this figure, the periods of the idealized systems representing the fully infilled frame (FI, T=0.077 s), a partially infilled frame (PI, with $50 \%$ of openings, $\mathrm{T}=0.153 \mathrm{~s}$ ) and a bare frame $(\mathrm{BF}, \mathrm{T}=0.675 \mathrm{~s})$ are indicated. It can be observed that the spectral acceleration, which corresponds to the bare frame, is only about half of the spectral acceleration, which corresponds to the partially infilled frame and a bit lower than the corresponding value for a fully infilled frame. It is clear that such a variation of the period of vibration will have a considerable effect on the dimensioning of the infilledframe members.

Table 2. Fundamental Periods and Mass Contributions of Various Percentage Openings

\begin{tabular}{|c|c|c|}
\hline Openings $\mathbf{a}_{\mathbf{w}}[\boldsymbol{\%}]$ & Period [sec] & Mass Contribution [\%] \\
\hline \hline 0 & 0.079 & 59.48 \\
\hline 25 & 0.137 & 85.76 \\
\hline 50 & 0.151 & 88.33 \\
\hline 75 & 0.244 & 87.26 \\
\hline 100 & 0.631 & 83.02 \\
\hline
\end{tabular}

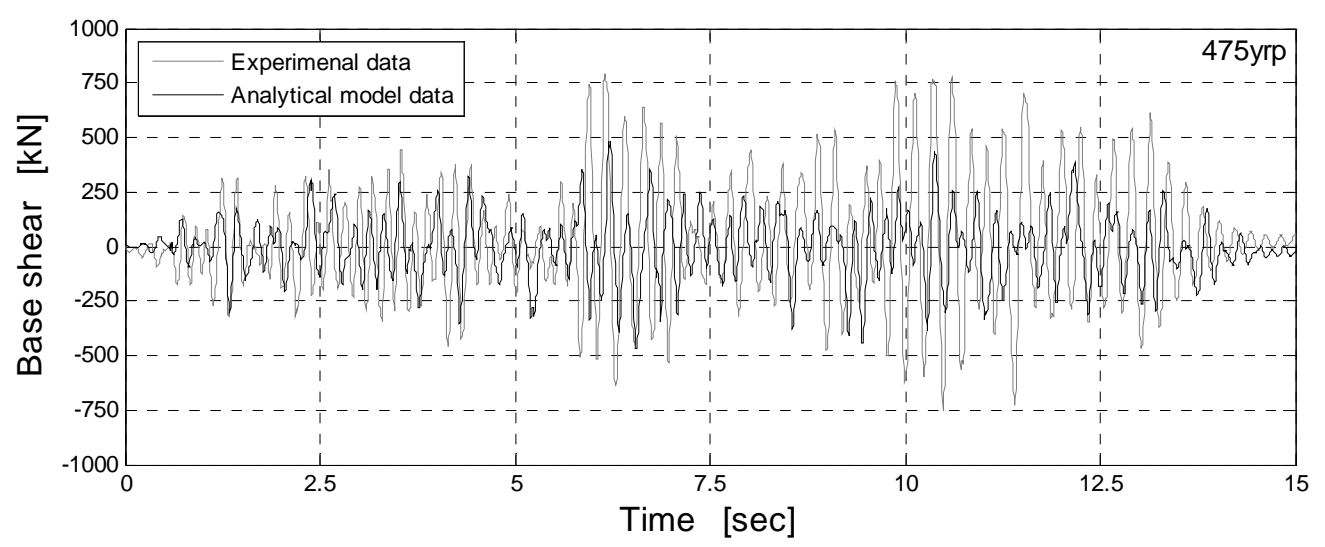

Fig. (9). Comparison of the Base Shear of the experimental infilled frame and the corresponding analytical model (475yrp). 


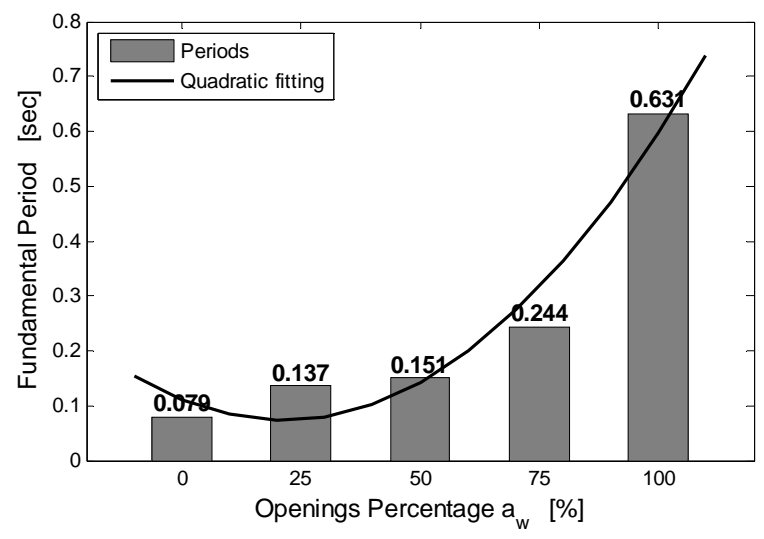

Fig. (10). Variation of fundamental period with opening size.

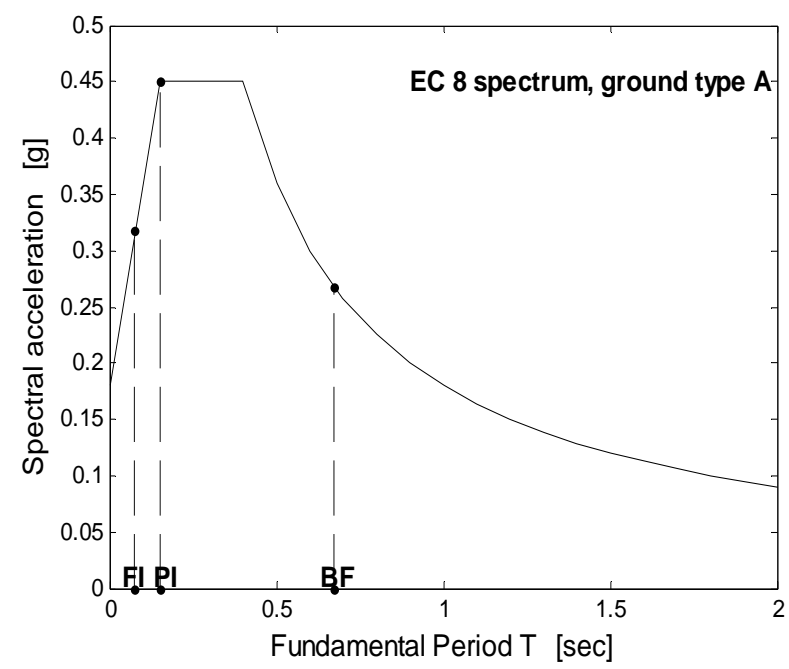

Fig. (11). Elastic acceleration spectra for a 475 yrp and the fundamental periods of a fully infilled frame (FI), a partially infilled frame $(\mathrm{PI})$ and a bare frame $(\mathrm{BF})$.

\subsection{Effect of Openings on Inter-Storey Drift Ratios}

The displacement variation along the building height is a typical way of illustrating the behaviour of a building in each storey. A better representation of the above is the use of the interstorey drift curve given in Fig. (12).

This figure shows the peak inter-storey drift ratio during the time-history analysis. The 'weakeness' of the second floor is more pronounced when larger openings in the infill panels are present. Three different cases of openings are illustrated and the resulting inter-storey drift ratio confirms the previous statement. This Figure is produced for acceleration time-histories of increasing return periods of 475 and 975 years. The 975 yrp analysis gives, as expected larger peak storey drifts for all various openings. The same conclusion was reached by Dorji et al. [46], who presented the interstorey drifts ratios for three different opening percentages.

Another way to demonstrate the influence of different percentage openings of the infilled panels is to plot base shear vs. inter-storey drifts (Fig. 13). It can be clearly seen, that the bare frame $\left(a_{w}=100 \%\right)$ has the highest inter-strorey drift and at the same time the lowest base shear value. On the other hand, the fully infilled frame $\left(\mathrm{a}_{\mathrm{w}}=0 \%\right)$ has the lowest drift-values and the highest base shear value, which is expected.

The variation of the base shear and top displacement with different infilled panel openings $\left(a_{w}\right)$ is examined in Fig. (14). The fitted curves imply that there is a quadratic relationship between base shear and displacement. It can be also noted that, the variation of base shear with increasing opening-size of the infilled panels is similar to that of the stiffness-reduction factor $\lambda$, which is shown in Fig. (4).
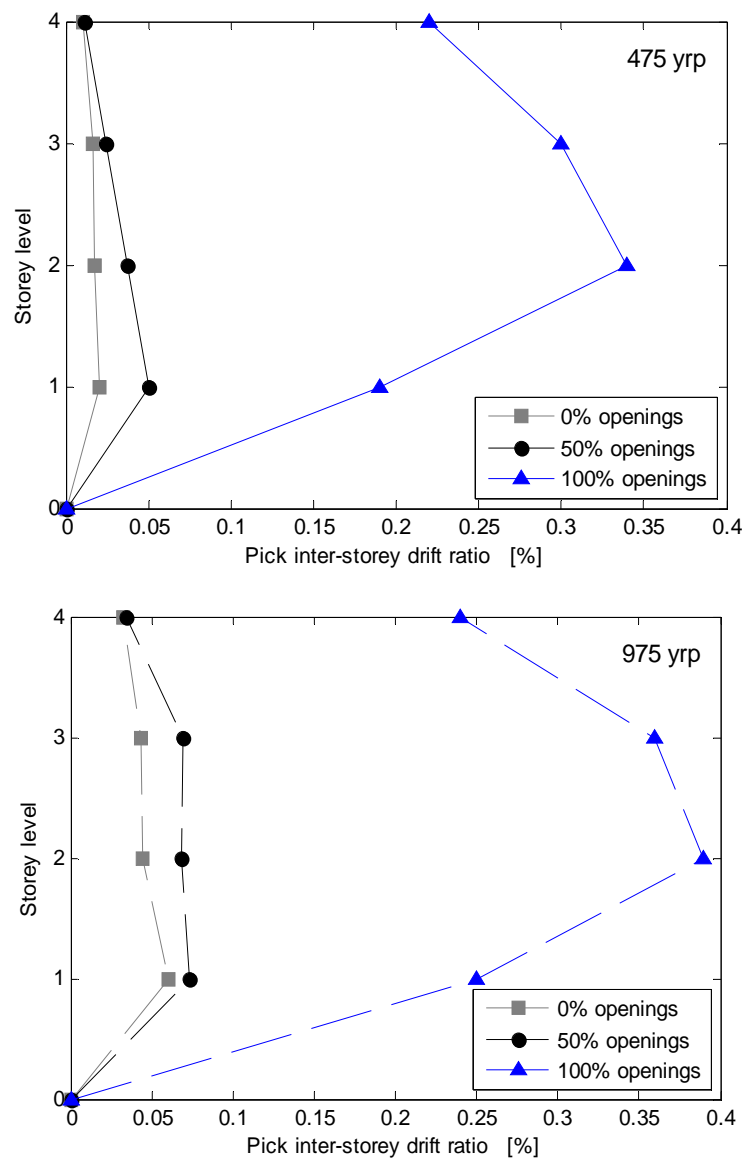

Fig. (12). Peak inter-storey drift at each storey level (475 \& 975 yrp).

The applicability of the proposed procedure for representing the openings in the walls was examined by introducing a 'pilotis', which may cause the soft-storey phenomenon during dynamic earthquake loads. This study investigated this problem by comparing two models:

a) A structure with solid infilled frames throughout the height of the building.

b) A structure without any infill at the first floor but with solid infilled frames in the rest of the floors, representing the presence of a 'pilotis'.

From Fig. (15), which shows the peak values of inter-storey drift ratios, it can be concluded that there is a strong soft-storey effect, which is captured by the proposed 

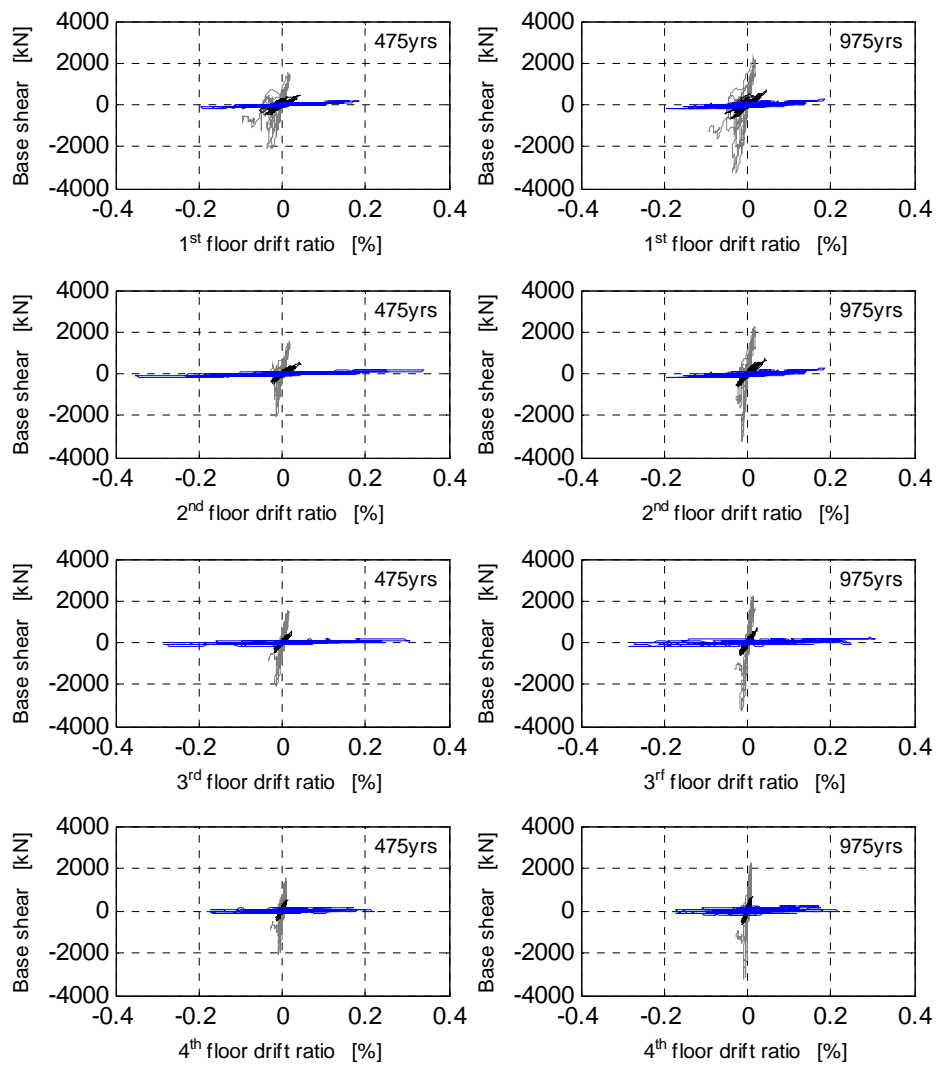

Fig. (13). Response-history of Base Shear with $1^{\text {st }}, 2^{\text {nd }}, 3^{\text {rd }} \& 4^{\text {th }}$ floor drift ration for $0 \%, 50 \% \& 100 \%$ open

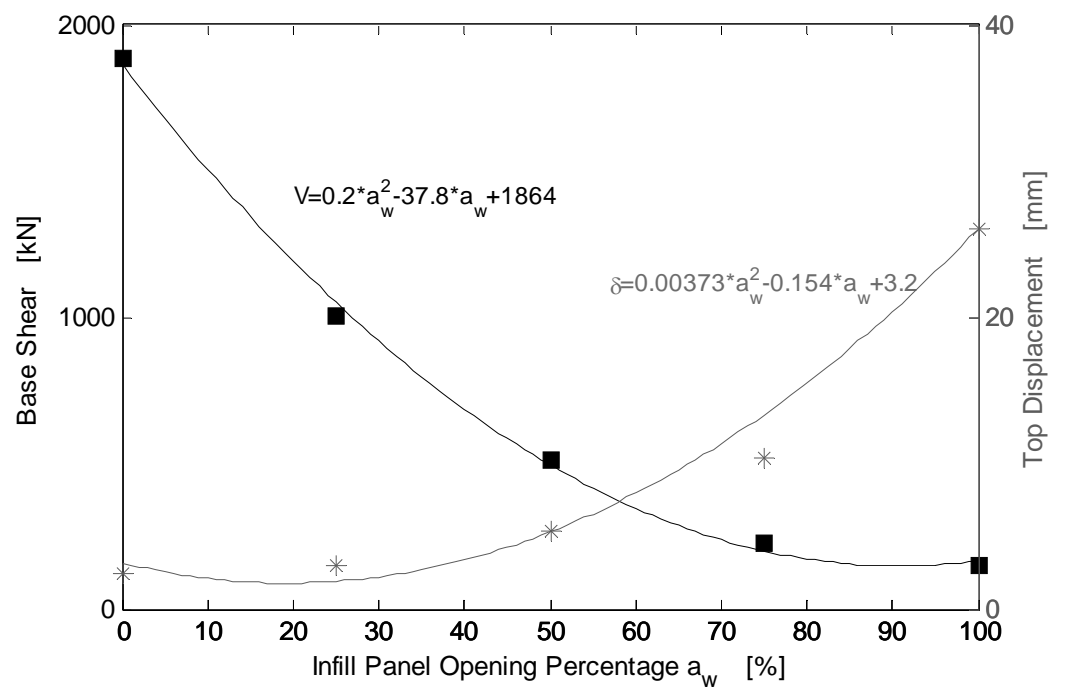

Fig. (14). Inter-storey drift showing the soft-storey effect after 15 load cycles (475 yrp).

modeling. The drift ratio value at the ground floor for case (b) is increased almost 3 times when compared to case (a). At the same time the drift ratios of the rest of the floors are essentially the same. This shows the vulnerability of such structures.

\section{CONCLUSIONS}

In this paper the attempts of researchers through many decades to model infill walls are summarized and the most commonly used macromodels are presented. One of the main difficulties to introduce infill walls, which are universally accepted as having a significant influence in the response of frames in the modeling of structures, is the absence of a way to represent openings in the infills. In this work, a reduction factor, $\lambda$, is proposed that can be used as a multiplication factor on well known equations to calculate the reduced equivalent width of compression struts, so as to be able to model infill walls with openings. The same reduction factor can be used in models of multiple-struts, so as to be able to 


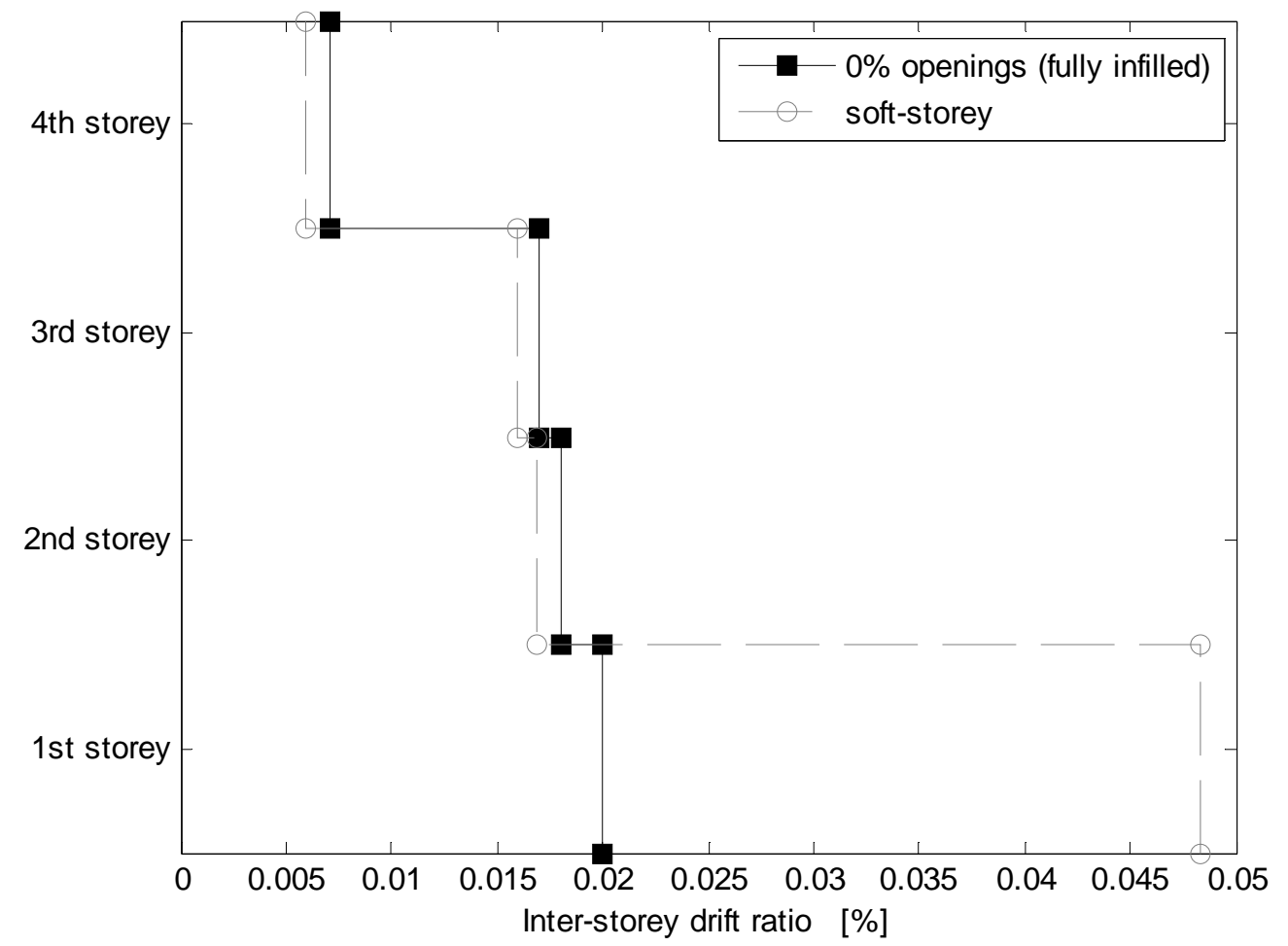

Fig. (15). Inter-storey drift showing the soft-storey effect after 15 load cycles (475 yrp).

idealize the nonlinear behaviour of infill walls with openings.

Using this approach, a two-strut model, which was calibrated against experimental results, was used to examine the effects of openings on the period of vibration of infilled structures with openings and on interstorey drifts.

It was shown that, as expected, the period of vibration of the structures is largely affected by the presence of the openings, which in turn has an effect on the earthquake load that such structures will be subjected to during an earthquake. The period of vibration of the infilled frame was found to be 9 times smaller than that of the bare frame, with the periods of vibration of the frames with openings to be somewhere inbetween, but without a clear trend.

Regarding the interstory drifts, it is shown that the 'weakeness' of a floor level is more pronounced when larger openings in the infill panels of the building are present. Specifically, the bare frame has peak interstory drifts of the order of 7 times larger than those of the fully infilled frame. The proposed procedure was also used to study the behaviour of a structure with a soft-story, and as it is shown, the interstory drift at the $1^{\text {st }}$ storey has increased dramatically, demonstrating the validity of the proposed model.

It can be therefore concluded, that the proposed reduction factor can be used to model infill frames with openings with satisfactory results. Further work needs to be done, using a larger number of ground motions and frame configurations, so as to fully validate this methodology.

\section{CONFLICT OF INTEREST}

None declared.

\section{ACKNOWLEDGEMENT}

None declared.

\section{REFERENCES}

[1] W.W. El-Dakhakhni, M. Elgaaly, and A.A. Hamid, "Three-Strut model for concrete masonry-infilled frames", J. Struct. Eng. ASCE, vol. 129(2), pp. 177-185, 2003.

[2] M.M. Kose, "Parameters affecting the fundamental period of RC buildings with infill walls", Eng. Struct., vol. 31, pp. 93-102, 2009.

[3] B.S. Smith, "Behavior of square infilled frames", J. Struct. Div. ASCE, ST1, pp. 381-403, 1966.

[4] B.S. Smith, and C. Carter, "A method of analysis for infilled frames", Proc. Instn. Civ. Engrs., vol. 44, pp. 31-48, 1969.

[5] A.W. Page, P.W. Kleeman, and M. Dhanasekar, "An In-Plane Finite Element Analysis Model for Brick Masonry", Proc. of a session held in conjunction with Structures Congress'85, Chicago, Ill, pp. 1-18, 1985.

[6] A.B. Mehrabi, P.B. Shing, M. Schuller, and J. Noland, "Experimental evaluation of masonry-infilled RC frames", J. Struct. Eng. ASCE, vol. 122 , no. 3, pp. 228-237, 1966.

[7] S.G. Buonopane, and R.N. White, "Pseudodynamic Testing of Masonry Infilled Reinforced Concrete Frame", J. Struct. Eng. ASCE, vol. 125, no. 6, pp. 578-589, 1999.

[8] M.H. Santhi, G.M.S. Knight, and K. Muthumani, "Evaluation of seismic response of soft-storey infilled frames", Comput. Concrete, vol. 2, no. 6, pp. 423-437, 2005.

[9] M.H. Santhi, G.M.S. Knight, and K. Muthumani, "Evaluation of Seismic performance of gravity load designed reinforced concrete Frames", J. Perform Construct. Facil., vol. 19, no. 4, pp. 277-282, 2005.

[10] T.C. Liauw, and K.H. Kwan, "Nonlinear behaviour of non-integral infilled frames", Comp. Struct., vol. 18, pp. 551-560, 1984.

[11] M. Dhanasekar, and A.W. Page, "Influence of brick masonry infill properties on the behaviour of infilled frames", Proc. Inst. Civ. Eng., London, Part 2, vol. 81, pp. 593-605, 1986.

[12] C.Z. Chrysostomou, "Effects of degrading infill walls on the nonlinear seismic response of two-dimensional steel frames", PhD thesis, Cornell University, Ithaca, N.Y, 1991.

[13] A. Saneinejad, and B. Hobbs, "Inelastic design of infilled frames", J. Struct. Eng. ASCE, vol. 121, no. 4, pp. 634-650, 1995. 
[14] C.Z. Chrysostomou, P. Gergely, and J.F. Abel, "A six-strut model for nonlinear dynamic analysis of steel infilled frames", Int. J. Struct. Stab. Dyn., vol. 2, no. 3, pp. 335-353, 2002.

[15] P.G. Asteris, "Lateral stiffness of brick masonry infilled plane frames", J. Struct. Eng. ASCE, vol. 129, no. 8, pp. 1071-1079, 2003.

[16] H.A. Moghaddam, "Lateral Load Behavior of Masonry Infilled Steel Frames with Repair and Retrofit", J. Struct. Eng. ASCE, vol. 130, no. 1, pp. 56-63, 2004.

[17] P.G. Asteris, "Closure to lateral stiffness of brick masonry infilled plane frames", J. Struct. Eng. ASCE, vol. 131, no. 3, pp. 523-524, 2005.

[18] P.G. Asteris, "Finite element micro-modeling of infilled frames", Electron. J. Struct. Eng., vol. 8, pp. 1-11, 2008.

[19] D.J. Kakaletsis, and C.G. Karayannis, "Experimental investigation of infilled reinforced concrete frames with openings", ACI Struct. J., vol. 106, no. 2, pp. 132-141, 2009.

[20] P.G. Asteris, C.Z. Chrysostomou, I.P. Giannopoulos, and E. Smyrou. "Masonry infilled reinforced concrete frames with openings", $3^{r d}$ International Conference on Computational Methods in Structural Dynamics and Earthquake Engineerin, COMPDYN 2011, Corfu, Greece, 2011

[21] H.A. Moghaddam, and P.J. Dowling, "The State of the Art in Infilled Frames", ESEE Research Report No. 87-2, Imperial College of Science and Technology, Civil Eng. Department, London, U.K, 1987.

[22] P.G. Asteris, S.T. Antoniou, D.S. Sophianopoulos, and C.Z. Chrysostomou, "Mathematical macromodeling of infilled frames: state of the art", J. Struct. Eng. ASCE, vol. 137, no. 12, pp. 15081517.

[23] F.G. Thomas, "The strength of brickwork", Struct. Eng., vol. 31, no. 2, pp. 44-46, 1953

[24] R.H. Wood, "The stability of tall buildings", Proc. Inst. Civ. Eng., vol. 11, pp. 69-102, 1958

[25] R.J. Mainstone, "Discussion on steel frames with brickwork and concrete infilling", Proc. Inst. Civ. Engrs., vol. 23, pp. 94-99, 1962.

[26] R.H. Wood, "Discussion on the stability of tall buildings", Proc. Instn. Civ. Engrs., vol. 12, pp. 517-518, 1959.

[27] S.V. Polyakov, "On the interaction between masonry filler walls and enclosing frame when loading in the plane of the wall", Translation in earthquake engineering, Earthquake Engineering Research Institute, San Francisco, pp. 36-42, 1960.

[28] M. Holmes, "Steel frames with brickwork and concrete infilling", Proc. Instn. Civ. Engrs., London, Part 2, vol. 19, pp. 473-478, 1961.

[29] B.S. Smith, "Lateral stiffness of infilled frames", J. Struct. Div. ASCE, vol. 88, no. ST6, pp. 183-199, 1962.

[30] B.S. Smith, "Methods for predicting the lateral stiffness and strength of multi-storey infilled frames", Building Sci., vol. 2, pp. 247-257, 1967.
[31] M. Hetenyi, "Beams on elastic foundations", Ann Arbor: University of Michigan Press, 1946.

[32] R.J. Mainstone, "On the stiffnesses and strengths of infilled frames", Proc. Inst. Civ. Engrs., Supp. (iv), pp. 57-90, 1971.

[33] R.J. Mainstone, and G.A. Weeks, "The influence of bounding frame on the racking stiffness and strength of brick walls", Proceedings of the $2^{\text {nd }}$ International Brick Masonry Conference, Building Research Establishment, Watford, England, pp. 165-171, 1970.

[34] R.J. Mainstone, "Supplementary note on the stiffness and strengths of infilled frames", Current Paper CP 13/74, Building Research Station, Garston, Watford, U.K, 1974.

[35] Federal Emergency Management Agency, "NEHRP Commentary on the Guidelines for the Seismic Rehabilitation of Buildings", FEMA-274, Applied Technology Council, Washington, DC, 1997.

[36] Federal Emergency Management Agency, "Evaluation of earthquake damaged concrete and masonry wall buildings: basic procedures manual", FEMA-306, Applied Technology Council, Washington, DC. 1998.

[37] F.J. Crisafulli, "Seismic Behaviour of Reinforced Concrete Structures with Masonry Infills", Ph.D. Thesis, University of Canterbury, Christchurch, New Zealand, 1997.

[38] F.J. Crisafulli, and A.J. Carr, "Proposed macro-model for the analysis of infilled frame structures", Bull. N.Z. Soc. Earthquack Eng., vol. 40, no. (2), pp. 69-77, 2007.

[39] A.J. Carr, RUAUMOKO. "Inelastic Dynamic Analysis", Department of Civil Engineering, University of Canterbury, Available at: http://www.ruaumoko.co.nz

[40] SeismoSoft (2009), "SeismoStruct - A Computer Program for the Static and Dynamic Analysis of Framed Structures", Available at http://www.seismosoft.com.

[41] A. Pinto, G. Verzeletti, J. Molina, H. Varum, R. Pinho, and E. Coelho, "Pseudo-Dynamic Tests on Non-Seismic Resisting RC Frames (Bare and Selective Retrofit Frames)", Joint Research Centre, Ispra, 1999.

[42] Campos-Costa, A.V. Pinto, "European Seismic Hazard Scenarios An Approach to the Definition of Input Motions for Testing and Reliability Assessment of Civil Engineering Structures", JRC Special Publication, no X.99.XX, ELSA, JRC - Ispra, Italy, 1999.

[43] F.J. Molina, P. Pegon, and G. Verzeletti, "Time-domain identification from Seismic Pesudoi-dynamic Test Results on Civil Engineering Specimens", 2nd International Conference on Identification in Engineering Systems, Wales, UK, 1999.

[44] ASCE Standard ASCE/SEI 41-06, "Seismic Rehabilitation of Existing Buildings", USA: American Society of Civil Engineers, 2007.

[45] CEN. "Eurocode 8: Design of structures for earthquake resistance. Part I: General rules, seismic action and rules for buildings", Brussels; 2004.

[46] J. Dorji and D.P. Thambiratnam, "Modelling and analysis of infilled frame structures under seismic loads", Open Construct Building Technol. J., vol. 3, pp. 119-126, 2009. 